\title{
Структурные и оптические свойства тонких пленок PbS:Fe
}

\author{
Е.В. Мостовщикова ${ }^{1)}$, В.И. Воронин ${ }^{1)}$, Л.Н. Маскаева ${ }^{2,3)}$, А.Д. Кутявина ${ }^{2)}$, Н.А. Чуфарова ${ }^{2)}$ \\ ${ }^{1}$ ИФМ УрО РАН, Екатеринбург, 620108, С. Ковалевской 18 \\ ${ }^{2}$ УрФУ, Екатеринбург, 620002, ул. Мира, 19 \\ ${ }^{3}$ ФГБОУ ВО Уральский институт ГПС МЧС России, Екатеринбург, 620062, ул. Мира, 22 \\ тел:+7 (343) 378-3810, эл. почта: mostovsikova@imp.uran.ru
}

DOI 10.34077/RCSP2019-29

Одним из методов управления характеристиками фоточувствительных слоев $\mathrm{PbS}$, которые широко применяются в различных областях оптоэлектроники, является введение в реакционную смесь допирующих добавок. В основном в литературе исследуются нанокристаллические пленки сульфида свинца и эффект уменьшения размера кристаллитов пленки при введении легирующих солей. При этом наблюдаемые изменения полупроводниковых характеристик связывается с размерным эффектом вследствие уменьшения размера частиц до близкого к размеру экситона ( 20 нм). В настоящей работе исследовано изменение свойств пленок $\mathrm{PbS}$, полученных методом гидрохимического осаждения, при введении соли железа (II). Добавка в виде $\mathrm{FeCl}_{2}$ выбрана, поскольку введение ионов $\mathrm{Fe}^{2+}$ может не только влиять на ширину запрещенной зоны $\mathrm{PbS}$, но и приводить к появлению ферромагнетизма [1], а значит указать новые пути модификации свойств $\mathrm{PbS}$. Чтобы исключить влияние размерного эффекта синтезированы пленки с размером кристаллитов больше 100 нм.

Пленки PbS:Fe толщиной 380-400 нм получены гидрохимическим осаждением на стеклянные подложки из цитратно-аммиачной ванны с добавлением $\mathrm{FeCl}_{2}$ от 0.05 до 5 ммоль/л. Кристаллическую структуру изучали методом рентгеновской дифракции на дифрактометре Дрон-4 с медным анодом в
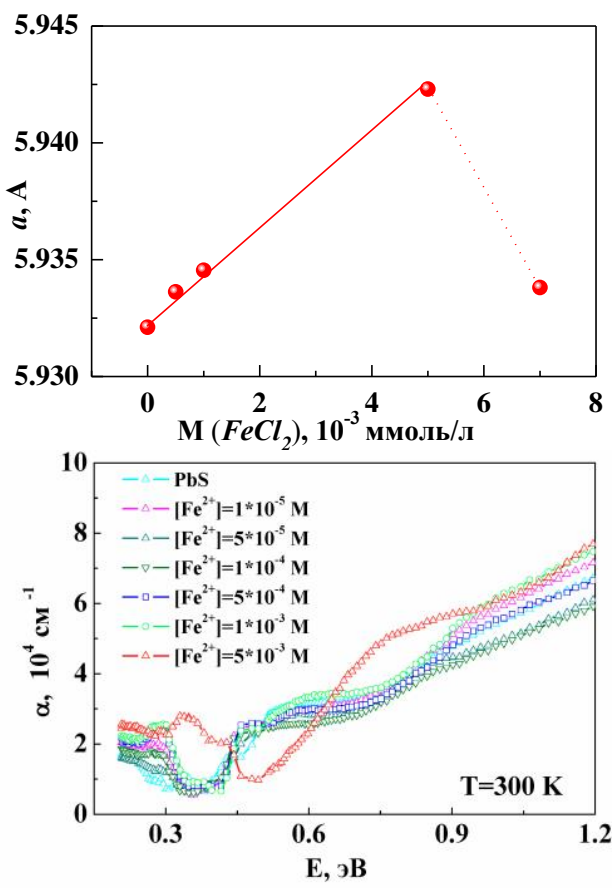

Рис.1 Зависимость параметра решетки от содержания $\mathrm{FeCl}_{2}$ (a) и спектры поглошения (б) пленок PbS:Fe. геометрии Брэгга-Брентано. Оптические исследования проводили в ближнем ИК диапазоне $(0.3<\mathrm{E}<1.2$ эВ) с использованием призменного спектрометра.

По данным XRD анализа введение $\mathrm{Fe}^{2+}$ в $\mathrm{PbS}$ не изменяет тип кристаллической структуры $\mathrm{PbS}$. При концентрации $\mathrm{FeCl}_{2}$ в растворе не более 1 ммоль/л параметр решетки $a$ увеличивается от $5.9321 \AA$ до 5.9423 $\AA$ (рис.1а). Поскольку ионный радиус $\mathrm{Pb}^{2+}$ больше, чем $\mathrm{Fe}^{2+}$, то наблюдаемое увеличение параметра $a$ можно связать с внедрением ионов $\mathrm{Fe}^{2+}$ в междоузлия $\mathrm{PbS}$. При увеличении концентрации $\mathrm{FeCl}_{2}$ в растворе до 5 ммоль/л параметр а уменьшается до $5.9338 \AA$, что указывает на замещение свинца железом. В работе [2] обнаружено уменьшение параметра решетки $\mathrm{PbS}$ и формирование твердого раствора $\mathrm{PbS}: \mathrm{Fe}$ с ростом содержания $\mathrm{Fe}^{2+}$, однако в работе [2] рассматривались более высокие уровни легирования, чем у нас.

При введении $\mathrm{FeCl}_{2}$ до 5 ммоль/л в спектрах поглощения наблюдается слабое уменьшение $\mathrm{E}_{\mathrm{g}}$ от 0.44 эВ для исходного $\mathrm{PbS}$ до 0.42 эВ, а при энергии 0.3 эВ появляется дополнительная полоса поглощения, интенсивность которой увеличивается с ростом концентрации допанта. (рис. 1б). Увеличение содержания $\mathrm{FeCl}_{2}$ до 5 ммоль/л приводит к значительному синему сдвигу края поглощения, Еg увеличивается до 0.58 эВ, и к сдвигу примесной полосы поглощения в сторону больших энергий. Таким образом, наблюдается корреляция в изменении параметров решетки и оптических свойств PbS:Fe вблизи края поглощения.

Работа выполнена при финансовой поддержке программы 211 правительства Российской Федерации № 02.А03.21.0006 и в рамках государственного задания ФАНО России (тема ”Поток“" № AAAA-A18-118020190112-8 и тема ”Спин“, № АAАAА18-118020290104-2) и по проекту УрО РАН № 18-10-2-37.

\section{Jumepamypa}

[1] S. Ravishankar, A.R. Balu, et al. // Optik. 2017. V.134. P.121-127

[2] O. Portillo Moreno, R. Gutierrez Perez, et al. // Optic. 2016. V.127. P. 10273-10282. 